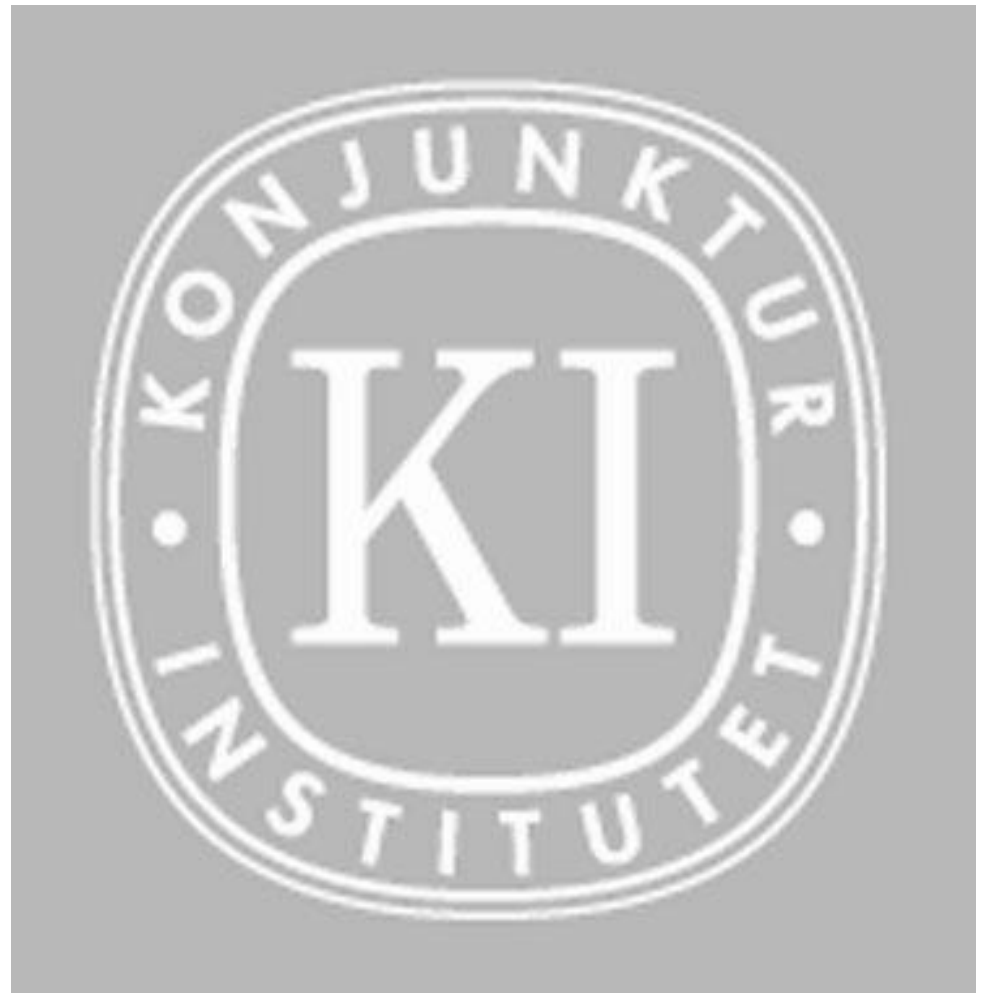

\title{
Policy Interest-Rate Expectations in Sweden: A Forecast Evaluation*
}

\author{
Meredith Beechey ${ }^{\#}$
}

Pär Österholm*

\begin{abstract}
* We are grateful to Jesper Hansson, Göran Hjelm and seminar participants at the National Institute of Economic Research for valuable comments. The views expressed in this paper are solely the responsibility of the authors and should not be interpreted as reflecting the views of the Executive Board of Sveriges Riksbank.

\# Sveriges Riksbank, 10337 Stockholm, Sweden

e-mail: meredith.beechey@riksbank.se Phone: +46 87870449
\end{abstract}

* National Institute of Economic Research, Box 3116, 10362 Stockholm, Sweden e-mail: par.osterholm@konj.se Phone: +46 84535948 
NIER prepares analyses and forecasts of the Swedish and international economy and conducts related research. NIER is a government agency accountable to the Ministry of Finance and is financed largely by Swedish government funds. Like other government agencies, NIER has an independent status and is responsible for the assessments that it publishes.

The Working Paper series consists of publications of research reports and other detailed analyses. The reports may concern macroeconomic issues related to the forecasts of the institute, research in environmental economics, or problems of economic and statistical methods. Some of these reports are published in their final form in this series, whereas others are previews of articles that are subsequently published in international scholarly journals under the heading of Reprints. Reports in both of these series can be ordered free of charge. Most publications can also be downloaded directly from the NIER home page. 


\begin{abstract}
In this paper, we evaluate two types of Swedish policy interest-rate expectations: survey expectations and expectations inferred from market pricing. The data are drawn from the most prominent survey of financial-market economists and from Swedish financial markets and the data are carefully matched by date to ensure comparability. Results show that both kinds of expectations suffer from bias and inefficiency and in terms of forecast precision there is no clear winner. We do find, though, evidence that the forecast accuracy of both kinds of policy-rate expectations has improved since the Riksbank started publishing its own policy-rate forecast, suggesting that this communication strategy has been beneficial from a policy perspective.
\end{abstract}

JEL Classification: E47, E52

Keywords: Survey data, Monetary policy, Sveriges Riksbank 


\section{Summary in Swedish}

I denna studie utvärderas två typer av reporänteförväntningar: enkätförväntningar och förväntningar baserade på marknadsprissättning. Data kommer från Sveriges viktigaste enkätundersökning av finansmarknadsekonomer och från svenska finansiella marknader; dessa har matchats noggrant efter datum så att de är jämförbara. Resultaten visar att båda typerna av förväntningar har problem med ineffektivitet samt frånvaro av väntevärdesriktighet och $\mathrm{i}$ termer av prognosprecision finns ingen klar vinnare. Vi finner dock tecken på att prognosprecisionen hos båda typerna av förväntningar har förbättrats sedan Riksbanken började publicera sin egen reporänteprognos. Detta indikerar att denna kommunikationsstrategi har varit förmånlig ur ett policyperspektiv. 


\section{Contents}

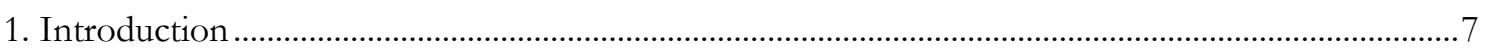

2. Data

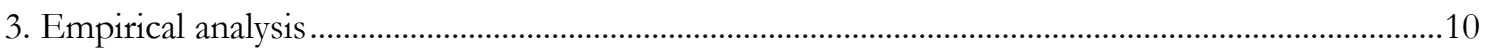

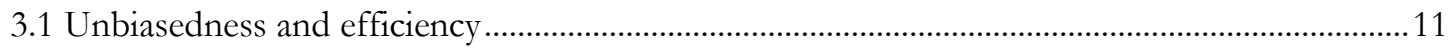

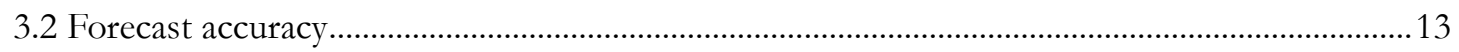

3.3 Forecast accuracy and central bank communication ................................................................. 14

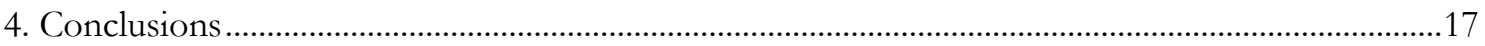

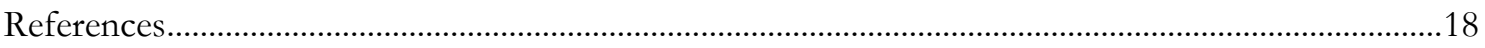

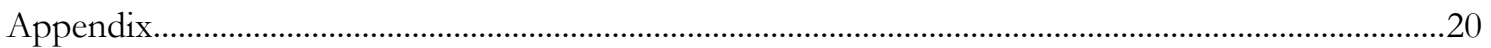





\section{Introduction}

Monetary policy hinges upon the management of expectations. Woodford (2003, p. 15) characterises this view as "not only do expectations about policy matter, but, at least under current conditions, very little else matters". In inflation-targeting economies, expectations about key macroeconomic variables including inflation, output growth and policy interest rates are of wide interest to policy makers, analysts and forecasters. Two important measures of private-sector expectations are survey expectations and expectations inferred from market pricing. The two measures have different benefits and shortcomings. Survey-based measures are often criticised for their lack of financial incentives for respondents to give thoughtful forecasts; see, for example, Gürkaynak and Wolfers (2005). Measures based on market pricing, on the other hand, are sensitive to empirical assumptions about credit spreads and risk premia. For example, interest-rate and inflation expectations inferred from derivatives contracts and bond yields rely upon assumptions about risk premia that are difficult to observe in good times and even harder to assess during times of financial turbulence; see Galati et al. (2011) for a discussion.

The purpose of this paper is to evaluate the forecasting properties of survey and market-based policy interest-rate expectations in Sweden. The analysis speaks to several questions. First, do privatesector expectations possess reasonable properties? For example, bias is a warning sign and inefficiency signals shortcomings in the way expectations are formed or measured. Second, which expectations should policy makers rely upon when the various measures of expectations do not coincide? Here, the relative forecast precision of the measures might be informative. In recent years, discrepancies between survey- and market-based expectations measures have arisen in several countries, including Sweden. Figure A1 in the appendix - which replicates parts of the information of a figure from the Riksbank's October 2010 Monetary Policy Report - illustrates the discrepancy between the survey-based and market-based expectations as well as the discrepancy with the Riksbank's own interest-rate forecast.

Third, and most contentiously, should the central bank publish its own policy-rate projection?1 Proponents of this policy argue that communicating the policy-rate path helps economic agents better understand monetary policy and grants the central bank more influence over longer-term interest rates, thereby improving the central bank's ability to achieve its macroeconomic objectives. Opponents argue that the policy-rate path is too uncertain to warrant being published and risks being interpreted as a statement of commitment. Nor has academic research arrived at a consensus. Some recent research, suggests that publishing the path might be beneficial, or at least not detri-

\footnotetext{
1 There is a fairly lively discussion among both academics and policy makers concerning the limits to central bank transparency; see, for example, Morris and Shin (2002), Svensson (2006), Blinder et al. (2008), Rudebusch (2008), van der Cruijsen et al. (2010) and Ehrmann et al. (2012).
} 
mental for economic outcomes; see, for example, Moessner and Nelson (2008), Rudebusch and Williams (2008) and Andersson and Hofmann (2010). However, Dale et al. (2011) argue that if the central bank publishes poor-quality forecasts then ultimately it risks becoming a source of distraction that is detrimental to the private sector's forecast precision. ${ }^{2}$ With the benefits uncertain, few central banks have so far chosen to publish policy-rate forecasts so there is accordingly little data with which to assess the effect on private-sector policy expectations. Sveriges Riksbank took the step relatively early - in February 2007 - thereby becoming one of the first central banks with an endogenous policy rate projection. ${ }^{3}$ Comparing policy-rate forecast precision before and after this date can shed light on the effect of the communication policy.

Our results show that the private sector's policy-rate expectations are neither unbiased nor efficient forecasts. Concerning forecast precision, we find there is no clear winner between survey expectations versus those inferred from market pricing. Interestingly, though, we find evidence that the forecasting precision of all types of policy-rate expectations has increased modestly since the Riksbank began publishing its own policy-rate projection.

The rest of this paper is organised as follows. Section 2 describes the data, Section 3 presents the empirical analysis and Section 4 concludes.

\section{Data}

Our data span the period September 2002 to January 2012 and are drawn from the most prominent survey of financial-market forecasters, Prospera, and from Swedish financial markets. We consider two real-time measures of expectations inferred from market pricing, one which has been calculated by the Riksbank using various financial contracts and assumptions about term premia (measure A) and another using only forward rate agreements and standardised assumptions about credit-market spreads and term premia (measure B). To ensure comparability of the information sets, expectations based on market pricing are calculated on the same dates the Prospera survey was conducted.

Survey-based expectations: The Prospera survey has been conducted four times each year and collects information from households, firms and forecasters working in financial markets. We fo-

\footnotetext{
${ }^{2}$ Dale et al. (2011) considered inflation forecasts in a highly stylised model but argue that this principle applies more broadly.

3 The Reserve Bank of New Zealand was the true pioneer when it comes to endogenous interest rate forecasts, publishing endogenous rate forecasts from 1998. Interestingly, though, it publishes its projection of the 90 -day bank bill rate, not its own policy rate (the official cash rate). In October 2005, Norway began publishing endogenous projections of the policy rate. Most recently, in January 2012, the Federal Reserve began publishing the end-of-year policy-rate forecasts of individual FOMC members.
} 
cus on the latter set of respondents, denoted "money-market players", of which there are typically 40 to 50 respondents. Respondents give their forecast of the Riksbank's policy rate at several horizons, from one quarter up to 5 years, and we use the average forecast in our analysis.

Expectations inferred from market pricing: Market interest rates embed not only policy expectations but also credit spreads and risk premia that reflect the nature of the financial instrument and the investment horizon. The forecast accuracy of market-inferred policy expectations thus depend both on the ability of the market to forecast the central bank's policy actions and the accuracy of the spread and premia adjustments. ${ }^{4}$ In light of this, we consider two market-based measures for Sweden:

Measure A: Policy-rate expectations inferred historically by the Riksbank using smooth NelsonSiegel type curves (Nelson and Siegel, 1987; Svensson, 1995) fitted to a range of financial instruments, including government bond yields, forward rate agreements (FRAs) and interest-rate swaps and futures. The underlying financial instruments and the assumptions about credit spreads and risk premia have varied over the years to suit data availability and market conditions. Using the parameters of the fitted curves, we extract policy expectations at exactly 3, 12 and 24 months ahead.

Measure B: Policy-rate expectations measured from FRAs without curve fitting but with a consistent real-time method for adjusting for credit spreads and a standardised interest-rate risk premia assumption. We use the fourth and eighth FRA contracts as indicators of policy expectations one and two years ahead. ${ }^{5}$ FRAs do not settle directly on the Riksbank's policy rate but on a three-month interbank borrowing rate which embodies a credit spread for term bank lending. We extract real-time estimates of the anticipated interbank three-month credit spread by comparing derivatives which settle on overnight rates in the future with those that settle on three-month rates. ${ }^{6}$ Finally, we assume a rule of thumb interest-rate risk premium of 1.5 basis

\footnotetext{
4 The presence of premia which make forward rates poor predictors of market rates is well documented in the literature; see, for example, Chernenko et al. (2004), Alsterlind and Dillén (2005) and Piazzesi and Swanson (2008).

${ }^{5}$ Because of the construction of the FRA, it is unsuitable to use the first FRA contract as a measure of expectations at the one-quarter horizon. We accordingly do not use it in this paper.

${ }^{6}$ Specifically, we observe rates on 3, 6, 9 and 12 month overnight indexed swaps which settle on overnight interbank borrowing rates for the following day. These contracts reflect expectations about average tomorrow-next interbank rates over the contract's life. Converting these rates to forward rates spanning 6-to-9, 9-to-12 and 6-to-12 months, it is then possible to compare the rates to those on FRA contracts that reflect expectations about 3-month interbank borrowing rates. This comparison is made immediately before IMM-settlement dates so that the contract horizons match. The difference between the overnight and three-month forward rates reveals the market's anticipation of the spread between three-month and overnight interbank borrowing rates 6 to 12 months ahead, that is, the extra compensation needed for taking on term bank credit risk in the future. We assume that the anticipated 6-to-12 month term credit spread ahead is a good indication of the same spread anticipated at 12 and 24 months ahead. We also subtract a further 10 basis points from the FRA rates (the sample average) which reflects the sample average spread between overnight interbank rates and the Riksbank's repo rate. Overlapping data on FRAs and overnight indexed swaps are available from September 2002. The data are sourced from Reuters.
} 
points per month, amounting to 0.18 and 0.36 percentage points at 12 and 24 months respectively. ${ }^{7}$

The survey-based and marked-inferred expectations are evaluated against outcomes of the Riksbank's policy rate - the repo rate - up to and including January 2012; the history of the policy rate is shown in Figure 1. Three different forecast horizons are evaluated - one quarter, one year and two years - with 38, 35 and 31 data points respectively. Figures A2 to A4 in the appendix show the forecast errors, defined as actual repo rate minus expectation, at the three horizons.

Figure 1. Repo rate in Sweden.

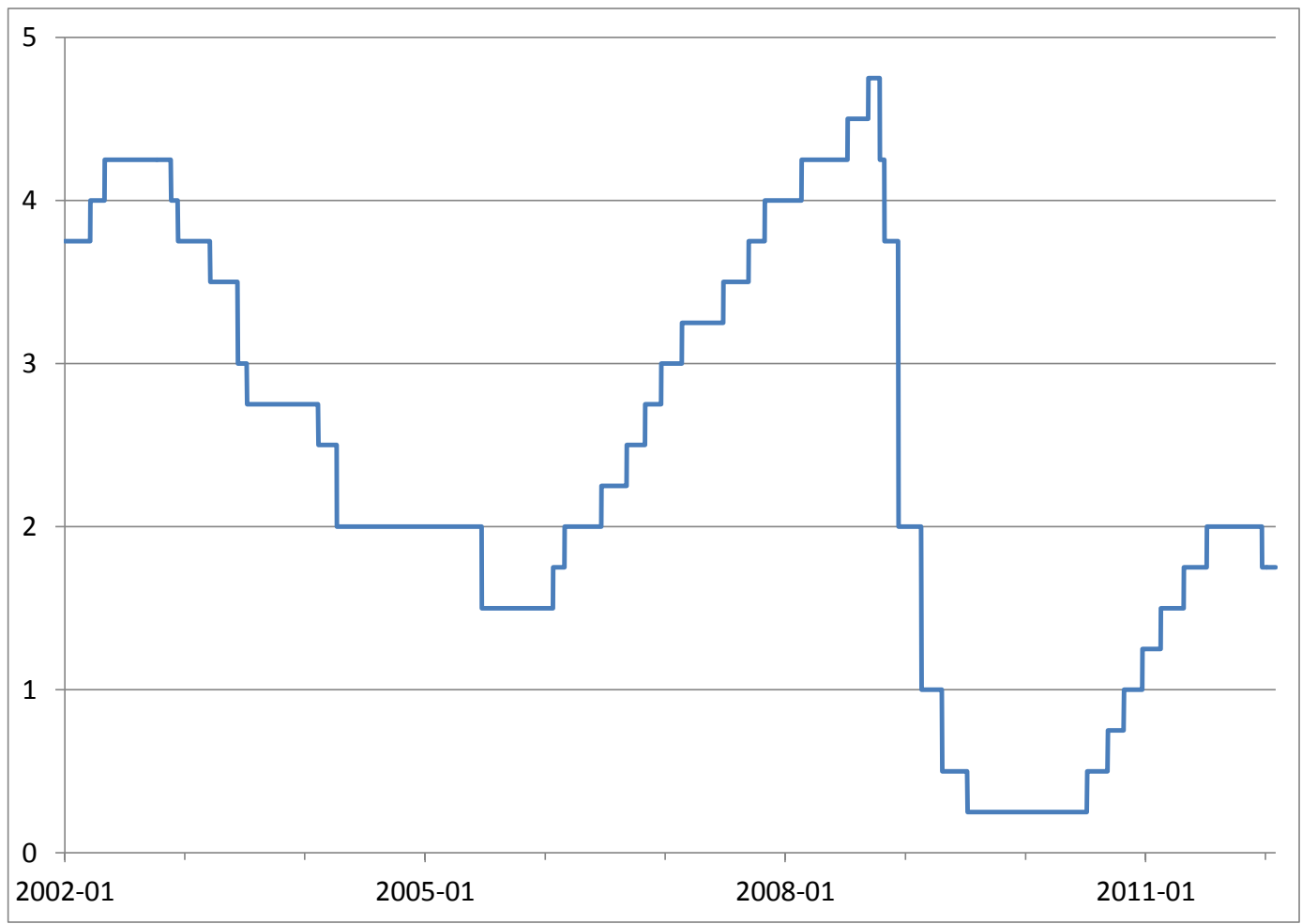

\section{Empirical analysis}

Our empirical analysis is divided into three parts. First, we test for unbiasedness and efficiency. Second, we evaluate the forecast accuracy of policy-rate expectations. These two stages are standard in the literature on forecast evaluation; see, for example, Mehra (2002), Mankiw et al. (2003), Baghestani (2008) and Jonsson and Österholm (2011). Third, we compare the forecast precision of poli-

7 This rule-of-thumb results in an average term premium adjustment similar to that proposed by Alsterlind and Dillén (2005) based on their analysis of forward rates from the government bond yield curve and is similar to that described by Piazzesi and Swanson (2008) for the US. 
cy-rate expectations in two subperiods to assess the impact of the Riksbank's communication strategy of publishing its own policy-rate projections.

\subsection{Unbiasedness and efficiency}

Defining the forecast error as $e_{t+h \mid t}=i_{t+h}-i_{t+h \mid t}$, where $i_{t+h}$ is the actual repo rate at time $t+h$ and $i_{t+h \mid t}$ is the forecast made at time $t$, the first column of Table 1 reports the mean errors. As is common in the macroeconomic literature, we also include a naive forecast as a neutral benchmark. As can be seen, all mean errors are negative, indicating that all measures of expectations at all horizons have been too high on average. The size of the mean error is larger the longer the forecast horizon. At the one-quarter horizon, average over-prediction ranges from -0.09 to -0.14 percentage points. At the two-year horizon, Prospera and market expectations have mean errors between -1.53 and -1.19 . The naïve forecast attracts a less pronounced mean error - it is only -0.56 .

Does this over-prediction constitute a significant bias? This can be tested by running the regression

$e_{t+h \mid t}=\lambda+\omega_{t}$

where $e_{t+h \mid t}$ is defined as above and $\omega_{t}$ is an error term. The null hypothesis $H_{0}: \lambda=0$ is then tested using Newey-West standard errors. ${ }^{8}$ As can be seen from Table 1, all measures at all horizons are biased at reasonable significance levels, except the naïve forecast. This bias is to some extent driven by the large forecast errors associated with the sharp easing of monetary policy during the financial crisis. However, while these forecast errors constitute part of the explanation, they are probably not the only cause for our findings. ${ }^{9}$

Biased forecasts constitute a violation of rational expectations under the commonly employed assumption that the forecaster has a symmetric quadratic loss function for the forecast errors. However, in reality we never know the loss function and therefore make no such claims here. ${ }^{10}$ Instead we simply note that this result could be considered a warning sign regarding the rationality of the expectations formation process.

\footnotetext{
${ }^{8}$ Newey-West standard errors are used to address the serial correlation in the residuals (which occurs by definition at the one- and two-year horizons when using quarterly frequency data).

${ }^{9}$ In order to investigate this, we conducted some additional regression analysis. At the one-quarter horizon, there is only one large forecast error associated with the crisis. Allowing for a dummy variable to remove the influence of this, there is still a significant bias for the Prospera data. Detailed results are not reported but are available upon request.

10 Recall that biased forecasts can be rational, for example if forecasters have asymmetric loss functions; see Elliott et al. (2008) for a discussion.
} 
Table 1. RMSEs and results from tests of bias and efficiency.

\begin{tabular}{|c|c|c|c|c|}
\hline & Mean error & Efficiency & RMSE & Theil's U \\
\hline \multicolumn{5}{|l|}{1 quarter } \\
\hline Prospera & $\begin{array}{l}-0.14^{b} \\
(0.07)\end{array}$ & $\begin{array}{l}-0.11 \\
(0.08)\end{array}$ & 0.46 & 0.82 \\
\hline Market measure A & $\begin{array}{l}-0.13^{c} \\
(0.07)\end{array}$ & $\begin{array}{l}-0.12 \\
(0.08)\end{array}$ & 0.46 & 0.82 \\
\hline Market measure $B$ & - & - & - & - \\
\hline Naive & $\begin{array}{l}-0.09 \\
(0.12)\end{array}$ & - & 0.56 & 1.00 \\
\hline \multicolumn{5}{|l|}{1 year } \\
\hline Prospera & $\begin{array}{l}-0.65^{b} \\
(0.30)\end{array}$ & $\begin{array}{l}-0.50^{a} \\
(0.11)\end{array}$ & 1.24 & 0.81 \\
\hline Market measure A & $\begin{array}{l}-0.73^{b} \\
(0.33)\end{array}$ & $\begin{array}{l}-0.53^{a} \\
(0.19)\end{array}$ & 1.35 & 0.89 \\
\hline Market measure B & $\begin{array}{l}-0.59^{c} \\
(0.31)\end{array}$ & $\begin{array}{l}-0.52^{b} \\
(0.19)\end{array}$ & 1.27 & 0.83 \\
\hline Naive & $\begin{array}{l}-0.26 \\
(0.45)\end{array}$ & - & 1.53 & 1.00 \\
\hline \multicolumn{5}{|l|}{2 years } \\
\hline Prospera & $\begin{array}{l}-1.30^{b} \\
(0.53)\end{array}$ & $\begin{array}{l}-0.95^{a} \\
(0.30)\end{array}$ & 2.08 & 0.93 \\
\hline Market measure A & $\begin{array}{l}-1.53^{a} \\
(0.55)\end{array}$ & $\begin{array}{l}-1.02^{a} \\
(0.27)\end{array}$ & 2.30 & 1.03 \\
\hline Market measure B & $\begin{array}{l}-1.19^{b} \\
(0.55)\end{array}$ & $\begin{array}{l}-0.99^{a} \\
(0.27)\end{array}$ & 2.07 & 0.93 \\
\hline Naive & $\begin{array}{l}-0.56 \\
(0.71)\end{array}$ & - & 2.23 & 1.00 \\
\hline
\end{tabular}

Note: "Mean error" gives $\hat{\lambda}$ from equation (1). "Efficiency" gives $\hat{\beta}$ from equation (2). Newey-West standard errors in parentheses ()$.{ }^{a},{ }^{b}$ and ${ }^{c}$ indicate significance at the one, five and ten percent level respectively. Regressions have 38, 35 and 31 observations at the one-quarter, one-year and two-year horizons. Theil's $U$ is the relative RMSE between a given expectation and a naïve forecast. If the expectation has a lower RMSE than the naïve forecast, Theil's $U$ is accordingly less than unity.

Next, we test for efficient use of macroeconomic data when forming policy-rate expectations. A straightforward test of efficient use of data is based on the regression

$e_{t+h \mid t}=\alpha+\beta_{1} i_{t}+v_{t}$

where $i_{t}$ is the repo rate at time $t$ and $v_{t}$ is an error term. Since $i_{t}$ was in the information set at time $t$, efficient use of data requires that it cannot explain variation in the forecast error. The null 
hypothesis $H_{0}: \beta=0$ is tested using a standard $t$-test again with Newey-West standard errors. Results are given in Table 1 .

One- and two-year ahead policy expectations prove to be inefficient forecasts in that they do not make full use of the information contained in the current policy rate. While bias - as noted above is not necessarily a sign of lack of rationality, inefficient use of data is incompatible with rational expectations. One-quarter horizon expectations do, however, appear to be efficient with respect to the current policy rate.

\subsection{Forecast accuracy}

As the next step in our assessment of the policy-rate expectations, we compare the forecasting accuracy of the various measures. RMSEs are presented in the third column of Table 1. Glancing through the table, in terms of RMSEs there is no clear winner between survey-based and marketinferred measures of policy expectations. At the one-quarter horizon, Prospera and market-pricing measure A enjoy the same RMSE. At the one and two-year horizons, the RMSEs of the Prospera data and market-pricing measure B are very similar in size. Measures A and B of expectations inferred from market pricing differ in their forecast accuracy, likely due to different practices in adjusting for credit spreads and risk premia. In all cases but one - market-pricing measure A at the two-year horizon - the RMSEs are lower than the naïve forecast.

We test more formally for differences in forecasting precision using a modified Diebold and Mariano test under the assumption of a quadratic loss function. ${ }^{11}$ This is based on the regression

$\left(e_{t+h \mid t}^{P}\right)^{2}-\left(e_{t+h \mid t}^{M}\right)^{2}=\delta+\chi_{t}$

where $e_{t+h \mid t}^{P}$ and $e_{t+h \mid t}^{M}$ are the forecast errors of the Prospera survey and the market expectations respectively and $\chi_{t}$ is an error term. The null hypothesis is that the forecasting accuracy of the Prospera survey is equal to that of the market-inferred expectations. This is tested by comparing a transformation of the $t$-statistic on $\hat{\delta}$ to the relevant critical value from the $t$-distribution. The results in Table 2 show that the null hypothesis can be rejected only for Prospera versus market-pricing measure $\mathrm{A}$ at the two-year horizon.

${ }^{11}$ We use the modified test of Harvey et al. (1997) rather than the orignial one suggested by Diebold and Mariano (1995) since our samples are fairly small. 
Overall, the survey-based and market-inferred measures of policy expectations tell similar stories about the path of policy expectations and realised forecast errors. At the one- and two-year horizons, all types of expectations underpredicted the extent of policy tightening that would occur during 2006 and 2007 and going into the financial crisis, all measures failed to predict the abrupt loosening of monetary policy during late 2008 and early 2009. Extracting policy expectations from market pricing is particularly difficult during times of financial turbulence, large portfolio reallocations and extraordinary central bank measures. Given these difficulties, it is remarkable that the survey and market-inferred measures have been so similar. Indeed, based on a decade of data, there is little evidence to suggest that either survey-based or market-based expectations are superior in forecast ability.

Table 2. Results from Diebold-Mariano test.

\section{$S^{*}$}

\begin{tabular}{ll}
\hline $\mathbf{1}$ quarter & \\
Market measure A & 0.67 \\
Market measure B & - \\
\hline $\mathbf{1}$ year & \\
\hline Market measure A & -1.48 \\
Market measure B & -0.52 \\
\hline $\mathbf{2}$ years & \\
\hline Market measure A & $-1.78^{\mathrm{c}}$ \\
Market measure B & 0.20
\end{tabular}

Note: $S^{*}$ is the tests statistic from the modified Diebold and Mariano test of Harvey et al. (1997). ${ }^{a}{ }^{b}$ and ${ }^{c}$ indicate significance at the one, five and ten percent level respectively. Regressions have 38,35 and 31 observations at the one-quarter, one-year and two-year horizons.

\subsection{Forecast accuracy and central bank communication}

As described in the introduction, publishing central bank interest-rate projections is a contentious issue policy. The Riksbank began publishing its own policy-rate forecast in February 2007 and has soon reached five years with this policy. Has this materially affected the nature of private-sector policy expectations? As the final step in our assessment of repo rate expectations in Sweden, we evaluate the forecast precision of policy expectations before and after the new communication strategy.

Specifically, we focus on the one-quarter ahead expectations and split the sample in two parts around February 2007: Period 1 spans September 2002 to January 2007 and Period 2 spans May 
2007 to September 2011, each period containing 19 observations. ${ }^{12}$ By focussing on the onequarter ahead expectations we take advantage of the largest possible number of observations for the exercise. ${ }^{13}$

Table 3 reports RMSEs for the full sample (column 1) and subsamples (columns 2 and 3). Comparing the two subsamples, RMSEs are actually larger post February 2007; this owes entirely to the exceptional error of the September 2008 forecast made just prior to the collapse of Lehman Brothers. In the following three months, and before even the next survey opportunity, the Riksbank cut interest rates by 2.75 percentage points. The sharp drop in the policy rate was a surprise not only for private forecasters but also for the Riksbank itself, whose own policy-rate projection from early September 2008 did not foresee impending cuts.

Excluding just the September 2008 forecast error as an outlier, the RMSE of the post-February 2007 sample drops substantially, to about half of its pre-February 2007 size. Importantly though, it should be noted that unlike the survey-based and financial-market inferred expectations, the RMSE of the naïve forecast is almost the same in the two samples. This suggests that something happened specifically amongst private-sector forecasters rather than to the macroeconomic environment more generally.

Table 3. RMSEs from one-quarter-ahead forecasts from different time periods.

\begin{tabular}{lcccc}
$\begin{array}{c}\text { Sept 2002- } \\
\text { Sept 2011 }\end{array}$ & $\begin{array}{c}\text { Sept 2002- } \\
\text { Jan 2007 }\end{array}$ & $\begin{array}{c}\text { May 2007- } \\
\text { Sept 2011 }\end{array}$ & $\begin{array}{c}\text { May 2007- } \\
\text { Sept 2011 } \\
\text { No outlier }\end{array}$ \\
Prospera & 0.46 & 0.23 & 0.61 & 0.14 \\
Market measure A & 0.46 & 0.23 & 0.61 & 0.12 \\
Naive & 0.56 & 0.34 & 0.72 & 0.35 \\
\hline
\end{tabular}

The number of observations is small in both sub-samples so, to assess whether the differences in the pre- and post-communication strategy RMSEs are significant, we turn to a bootstrap exercise. ${ }^{14}$ It is conducted the following way:

I. For a given measure - Prospera or Market measure A - generate a Period 1 bootstrap sample with 19 observations by sampling (with replacement) squared forecast errors from the original sequence of squared forecast errors originating from the period September 2002 to January 2007.

\footnotetext{
12 January 2007 is the date of the last Prospera survey conducted before the Riksbank's change in communication strategy and May 2007 the date of the first survey conducted after this change.

13 The one-step-ahead forecast is also the the horizon studied by Dale et al. (2011).

${ }^{14}$ More traditional tests would require a larger number of observations than we have available here.
} 
II. For a given measure, generate a Period 2 bootstrap sample with 18 observations by sampling (with replacement) forecast errors from the original sequence of squared forecast errors originating from the period May 2007 to September 2011 (excluding the outlier).

III. For a given measure, calculate $D^{i}=R M S E_{1}^{i}-R M S E_{2}^{i}$, that is, the difference in RMSEs between "Period 1" and "Period 2" for measure $i$.

IV. Repeat steps I to III 20000 times.

This provides us with two bootstrap distributions for differences in RMSEs between the two periods - one for each measure. If a difference of zero or smaller is found to be rare, we conclude that the observed difference in RMSEs is statistically significant. It turns out that for the Prospera expectations, 4.9 percent of the bootstrap sample has an RMSE difference that is smaller than zero. The corresponding number for Market pricing A is 1.1 percent (see Figure 2). Hence, for both measures the drop in RMSEs between the pre- and post-communication samples is significant at conventional levels, but the evidence is stronger for the market-inferred expectations.

Figure 2. Bootstrap distributions of RMSE differences between periods.
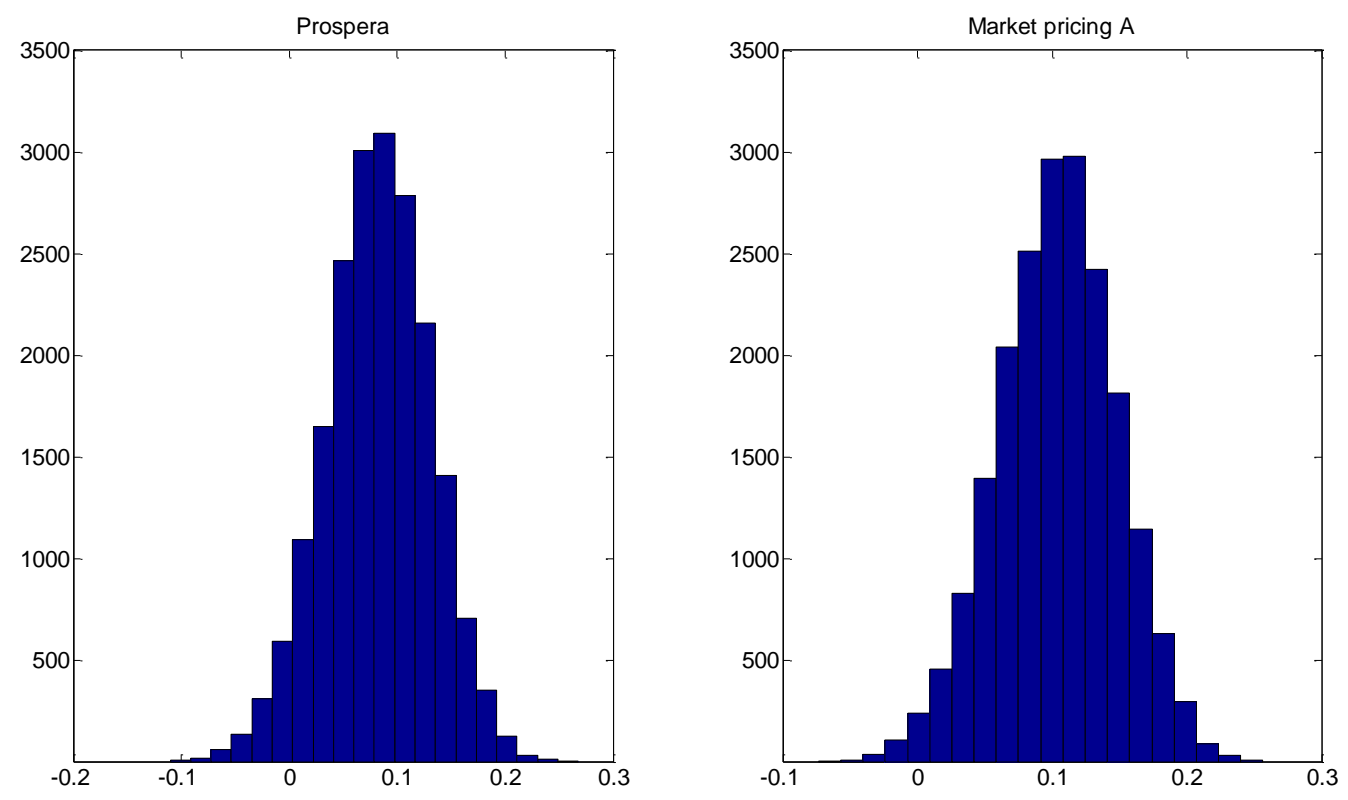

Note: The difference is given on the horizontal axis and is defined as the Period 1 RMSE minus the Period 2 RMSE. 20000 bootstrap replications were conducted for each distribution.

Summing up this exercise, we find evidence that the Riksbank's policy of communicating its policyrate forecasts has been associated with an increase in private-sector policy-rate forecast precision. 
Whether the policy has been causal or the improvement owes to other factors is difficult to establish. Given the financial and economic turbulence that has emerged since 2007 it is hard to argue that the forecast environment has become more stable or benign, leaving open the possibility that the Riksbank's communication policy has indeed assisted forecasters. That central-bank forecasts affect private-sector forecasts is consistent with the information-revealing role of the central bank see, for example, Romer and Romer (2000) - and of importance for the management of interestrate expectations.

\section{Conclusions}

In this paper, we have evaluated the forecasting properties of repo rate expectations in Sweden. At the one and two-year forecast horizons, both survey-based measures and market-pricing inferred measures of policy-rate expectations are biased and inefficient. These results are perhaps not too surprising given that survey-based forecasts of Swedish inflation and wage-growth have been shown to have similar shortcomings; see Jonsson and Österholm (2011, 2012). And despite the frequently cited disadvantages of both types of policy expectations, neither stand out as a clear winner concerning forecast accuracy.

Our results also indicate a modest improvement in the forecast precision of near-term policy expectations of private actors since the Riksbank began publishing its own policy-rate projection. This finding adds some empirical evidence to the discussion of the costs and benefits of central banks publishing their own policy-rate forecasts, a discussion that to date has largely been theoretical. A likely mechanism is that by making its forecasts more transparent the central bank provides information about its reaction function and methods that private-sector forecasters can employ in their own assessments. While our results should not be over-interpreted - we present evidence for one country - they are suggestive that the publication strategy yields benefits. 


\section{References}

Alsterlind, J. and Dillén, H. (2005), "Monetary Policy Expectations and Forward Premia", Sveriges Riksbank Economic Review 2005:2, 39-53.

Andersson, M. and Hofmann, B. (2010), "Gauging the Effectiveness of Quantitative Forward Guidance: Evidence from Three Inflation Targeters", In: Cobham, D., Eitrheim, Ø., Gerlach, S. and Qvigstad, J. F. (eds), Twenty Years of Inflation Targating. Lessons Learned and Future Prospects, Cambridge University Press, Cambridge.

Baghestani, H. (2008), "Federal Reserve versus Private Information: Who Is the Best Unemployment Rate Predictor?", Journal of Policy Modeling 30, 101-110.

Blinder, A. S., Ehrmann, M., Fratzscher, M., De Haan, J. and Jansen, D.-J. (2008), "Central Bank Communication and Monetary Policy: A Survey of the Theory and Evidence", Journal of Economic Literature 46, 910-945.

Chernenko, S., Schwarz, K. and Wright, J. H. (2004), "The Information Content of Forward and Futures Prices: Market Expectations and the Price of Risk" International Finance Discussion Papers 808, Board of Governors of the Federal Reserve System.

Dale, S., Orphanides, A. and Österholm, P. (2011), "Imperfect Central Bank Communication: Information versus Distraction", International Journal of Central Banking 7, 3-39.

Diebold F. X. and Mariano R. S. (1995), "Comparing Predictive Accuracy", Journal of Business and Economic Statistics 13, 253-263.

Ehrmann, M., Eijffinger, S. and Fratzscher, M. (2012), “The Role of Central Bank Transparency for Guiding Private Sector Forecasts”, Scandinavian Journal of Economics 114, 1018-1052.

Elliott, G., Komunjer, I. and Timmermann, A. (2008), "Biases in Macroeconomic Forecasts: Irrationality or Asymmetric Loss?", Journal of the European Economic Association 6, 122-157.

Galati, G., Poelhekke, S. and Zhou, C. (2011), "Did the Crisis Affect Inflation Expectations?”, International Journal of Central Banking 7, 167-207.

Gürkaynak, R. and Wolfers, J. (2005), "Macroeconomic Derivatives: An Initial Analysis of MarketBased Macro Forecasts, Uncertainty and Risk", In: Frankel, J. and Pissarides, C. (eds), NBER International Seminar on Macroeconomics, MIT Press, Boston.

Harvey, D., Leybourne, S. and Newbold, P. (1997), "Testing the Equality of Prediction Mean Squared Errors”, International Journal of Forecasting 13, 281-291.

Jonssson, T. and Österholm, P. (2011), “The Forecasting Properties of Survey-Based Wage-Growth Expectations", Economics Letters 113, 276-281.

Jonsson, T. and Österholm, P. (2012), "The Properties of Survey-Based Inflation Expectations in Sweden", Empirical Economics 42, 79-94. 
Mankiw, N. G., Reis, R., Wolfers, J. (2003), “Disagreements about Inflation Expectations”, NBER Macroeconomics Annual 18, 209-248.

Mehra, Y. P. (2002), "Survey Measures of Expected Inflation: Revisiting the Issues of Predictive Content and Rationality", Federal Reserve Bank of Richmond Quarterly Review 88, 17-36.

Moessner, R. and Nelson, W. R. (2008), "Central Bank Policy Rate Guidance and Financial Market Functioning", International Journal of Central Banking 4, 193-226.

Morris, S. and Shin, H. S. (2002), "Social Value of Public Information", American Economic Review 92, 1521-1534.

Nelson, C. R. and Siegel, A. F. (1987), "Parsimonious Modeling Of Yield Curves", Journal of Business 60, 473-489.

Piazzesi, M. and Swanson, E. (2008) "Futures Prices as Risk-Adjusted Forecasts of Monetary Policy”, Journal of Monetary Economics 55, 677-691

Romer, C. D. and Romer D. H. (2000), "Federal Reserve Information and the Behavior of Interest Rates", American Economic Review 90, 429-457.

Rudebusch, G. D. (2008), "Publishing Central Bank Interest Rate Forecasts”, Federal Reserve Bank of San Francisco Economic Letter 2008-02.

Svensson, L. E. O. (1995), "Estimating Forward Interest Rates with the Extended Nelson and Siegel Method", Sveriges Riksbank Quarterly Review 1995:3, 13-26.

Svensson, L. E. O. (2006), "Social Value of Public Information: Morris and Shin (2002) Is Actually Pro-Transparency, Not Con”, American Economic Review 96, 448-452.

van der Cruijsen, C. A. B., Eijffinger, S. C. W. and Hoogduin, L. H. (2010), "Optimal Central Bank Transparency”, Journal of International Money and Finance 29, 1482-1507.

Woodford, M. (2003), Interest and Prices: Foundations of a Theory of Monetary Policy, Princeton University Press, Princeton. 


\section{Appendix}

Figure A1. Repo rate, Riksbank forecast and market expectations in Sweden, October 2010.

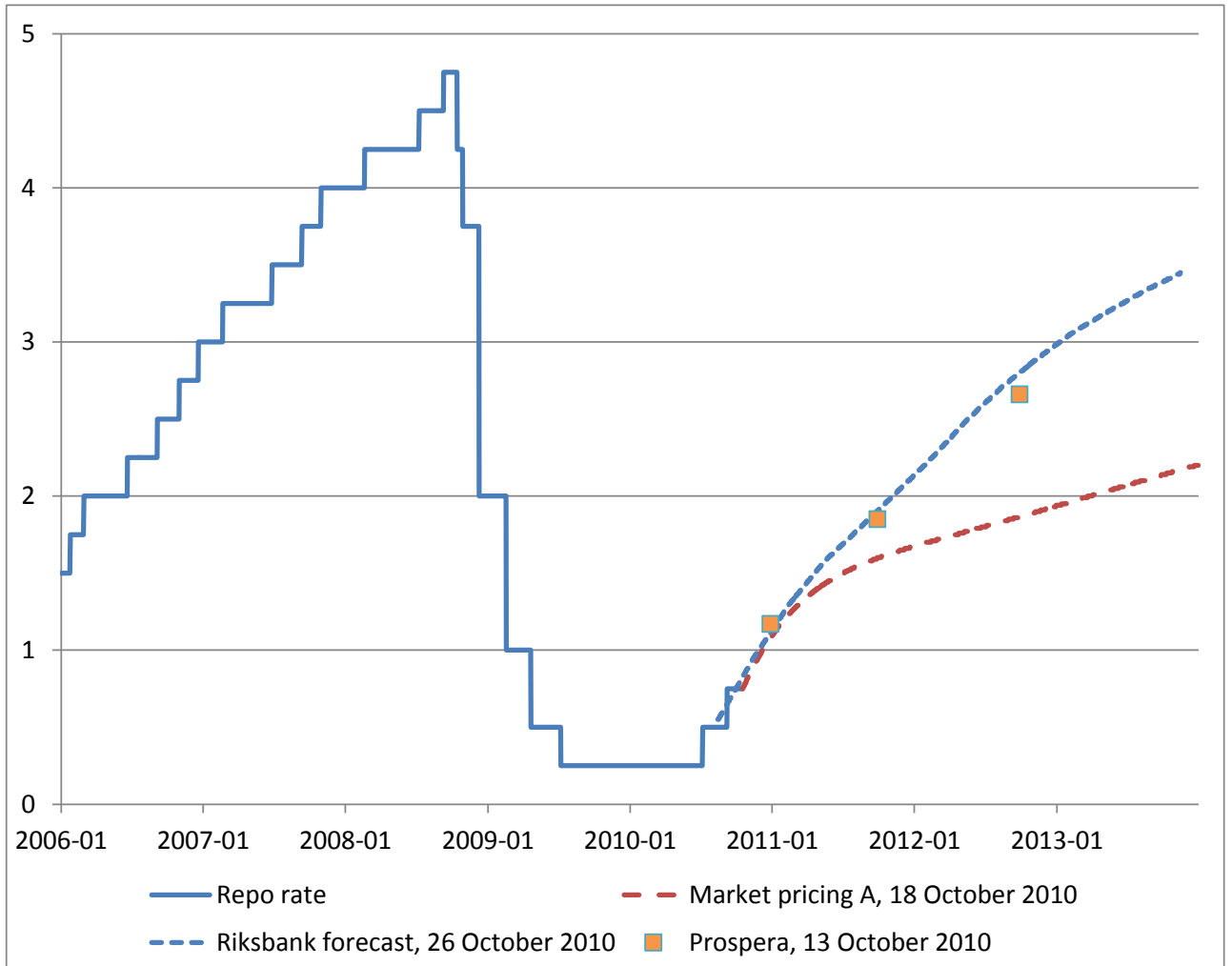

Note: This figure replicates parts of the information of Figure 1:8 in the Riksbank's October 2010 Monetary Policy Report.

Figure A2. Forecast errors at the one-quarter horizon.

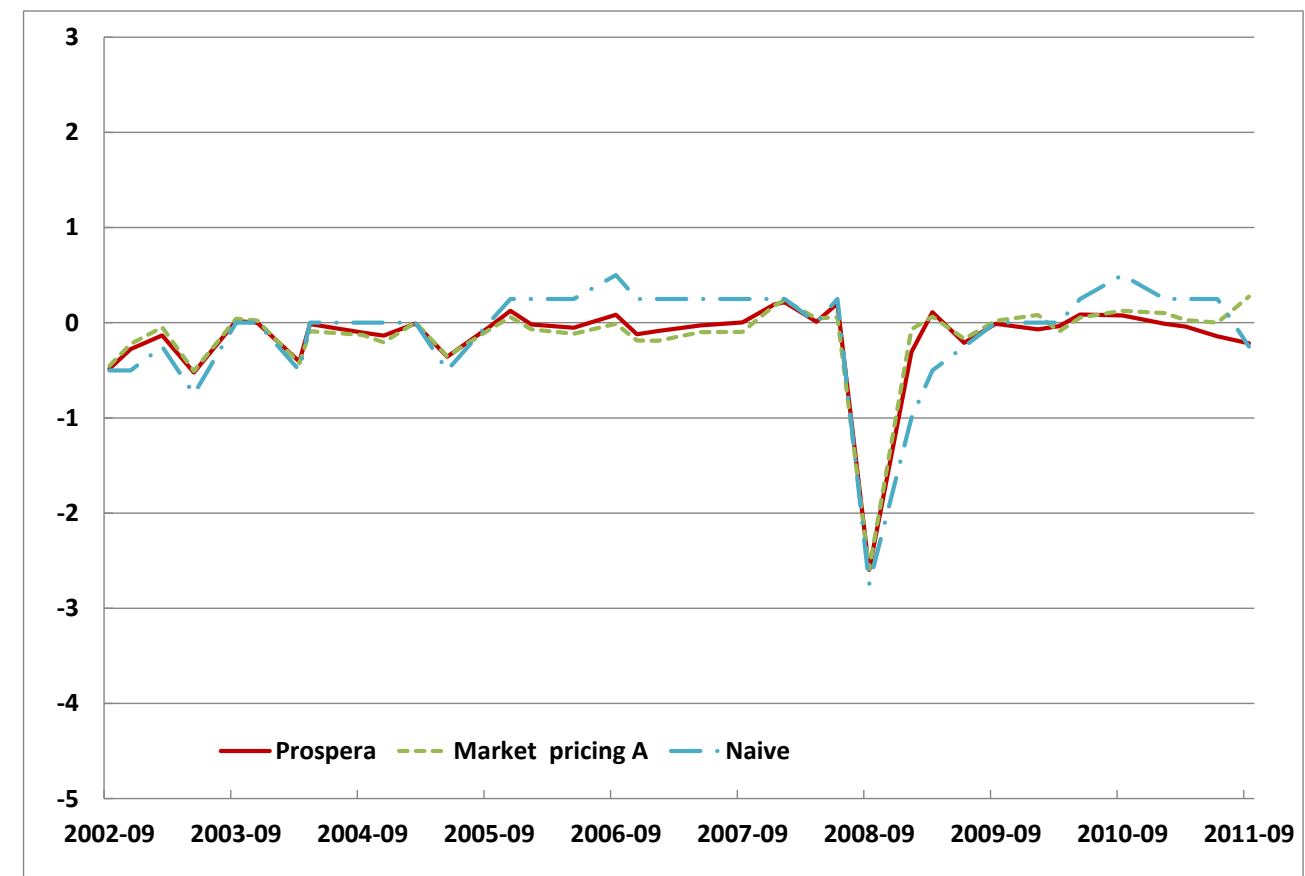

Note: Date refers to when forecast was made 
Figure A3. Forecast errors at the one-year horizon.

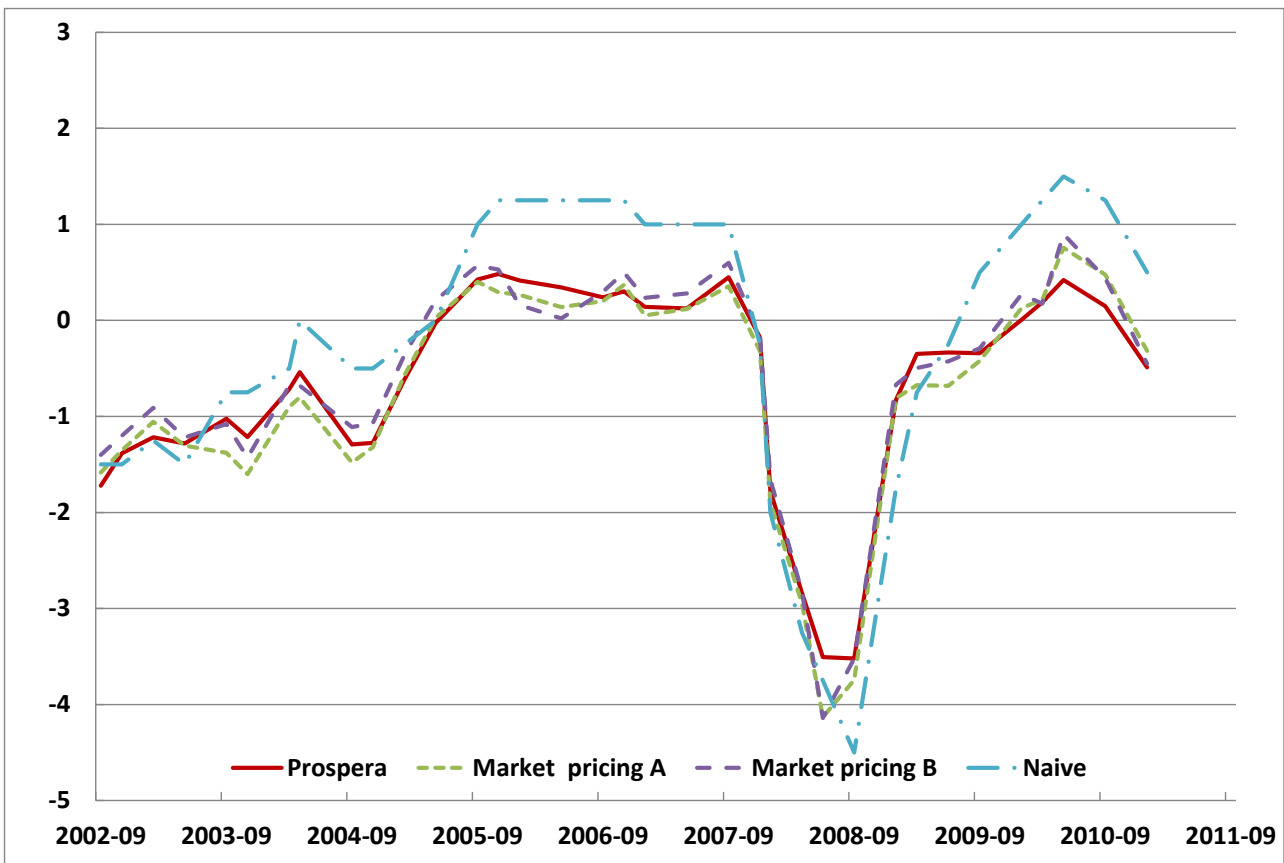

Note: Date refers to when forecast was made

Figure A4. Forecast errors at the two-year horizon.

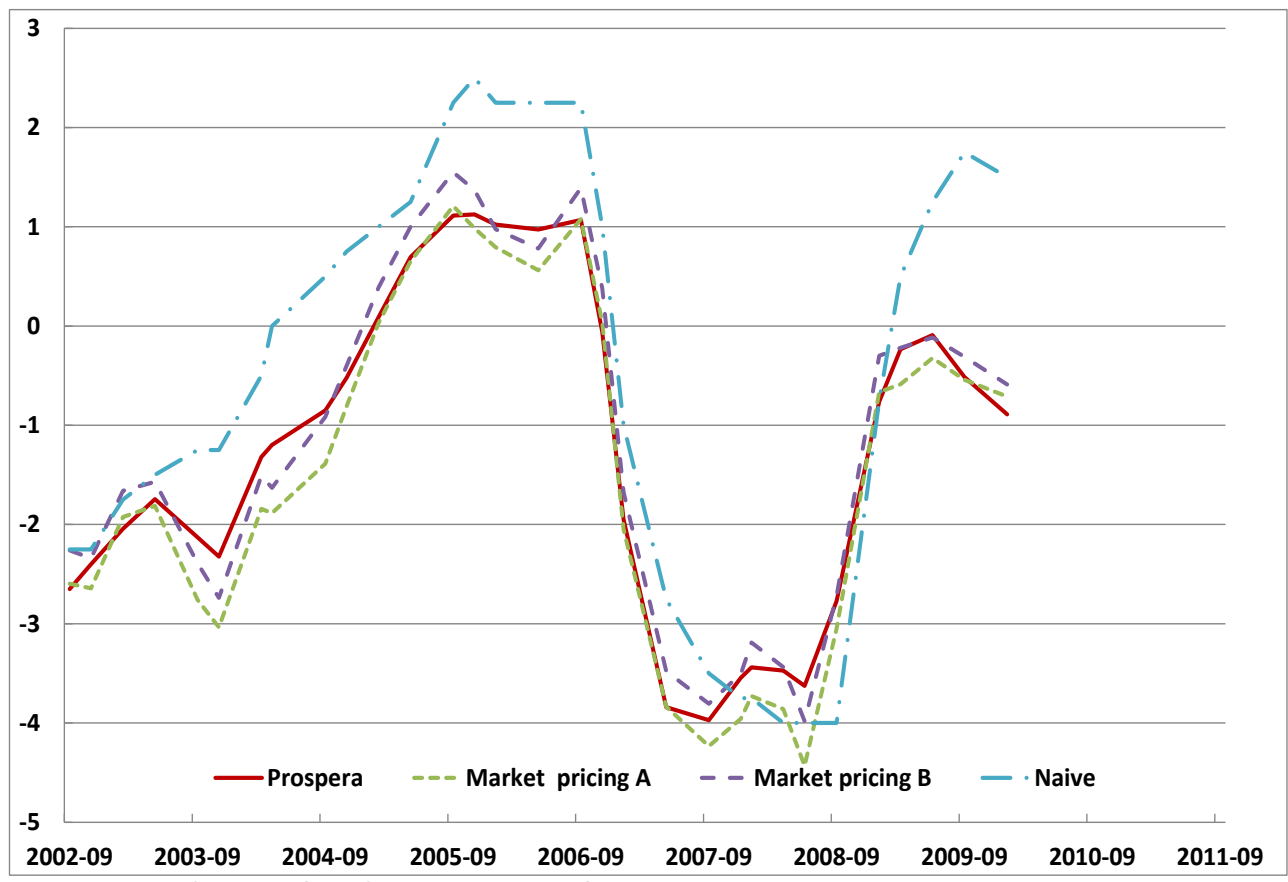

Note: Date refers to when forecast was made. 


\section{Titles in Working Paper Series/Specialstudier}

Tidigare publicerade Working Paper finns på www.konj.se

\begin{tabular}{|c|c|c|c|}
\hline No & Author & Title & Year \\
\hline 101 & Östblom, Göran & $\begin{array}{l}\text { Nitrogen and Sulphur Outcomes of a Carbon Emis- } \\
\text { sions Target Excluding Traded Allowances - } \\
\text { An Input-Output Analysis of the Swedish Case }\end{array}$ & 2007 \\
\hline 102 & $\begin{array}{l}\text { Hammar, Henrik and } \\
\text { Ása Löfgren }\end{array}$ & $\begin{array}{l}\text { Explaining adoption of end of pipe solutions and } \\
\text { clean technologies - Determinants of firms' invest- } \\
\text { ments for reducing emissions to air in four sextors in } \\
\text { Sweden }\end{array}$ & 2007 \\
\hline 103 & $\begin{array}{l}\text { Östblom, Göran and } \\
\text { Henrik Hammar }\end{array}$ & $\begin{array}{l}\text { Outcomes of a Swedish Kilometre Tax. An Analysis } \\
\text { of Economic Effects and Effects on NOx Emissions }\end{array}$ & 2007 \\
\hline 104 & $\begin{array}{l}\text { Forsfält, Tomas, } \\
\text { Johnny Nilsson and } \\
\text { Juhana Vartianinen }\end{array}$ & $\begin{array}{l}\text { Modellansatser i Konjunkturinstitutets medel- } \\
\text { fristprognoser }\end{array}$ & 2008 \\
\hline 105 & Samakovlis, Eva & $\begin{array}{l}\text { How are Green National Accounts Produced in Prac- } \\
\text { tice? }\end{array}$ & 2008 \\
\hline 106 & $\begin{array}{l}\text { Markowski, Alek, } \\
\text { Kristian Nilsson and } \\
\text { Marcus Widén }\end{array}$ & $\begin{array}{l}\text { Strukturell utveckling av arbetskostnad och priser i } \\
\text { den svenska ekonomin }\end{array}$ & 2011 \\
\hline 107 & $\begin{array}{l}\text { Forslund, Johanna, } \\
\text { Per Johansson, Eva } \\
\text { Samakovlis and Maria } \\
\text { Vredin Johansson }\end{array}$ & $\begin{array}{l}\text { Can we by time? Evaluation. Evaluation of the } \\
\text { government's directed grant to remediation in Sweden }\end{array}$ & 2009 \\
\hline 108 & $\begin{array}{l}\text { Forslund, Johanna } \\
\text { Eva Samakovlis, Maria } \\
\text { Vredin Johansson and } \\
\text { Lars Barregård }\end{array}$ & $\begin{array}{l}\text { Does Remediation Save Lives? } \\
\text { On the Cost of Cleaning Up } \\
\text { Arsenic-Contaminated } \\
\text { Sites in Sweden }\end{array}$ & 2009 \\
\hline 109 & $\begin{array}{l}\text { Sjöström, Magnus and } \\
\text { Göran Östblom }\end{array}$ & $\begin{array}{l}\text { Future Waste Scenarios for Sweden on the Basis of a } \\
\text { CGE-model }\end{array}$ & 2009 \\
\hline 110 & Österholm, Pär & $\begin{array}{l}\text { The Effect on the Swedish Real Economy of the Fi- } \\
\text { nancial Crisis }\end{array}$ & 2009 \\
\hline 111 & Forsfält, Tomas & $\begin{array}{l}\text { KIMOD } 2.0 \text { Documentation of changes in the model } \\
\text { from January } 2007 \text { to January } 2009\end{array}$ & 2009 \\
\hline 112 & Österholm, Pär & $\begin{array}{l}\text { Improving Unemployment Rate Forecasts Using } \\
\text { Survey Data }\end{array}$ & 2009 \\
\hline 113 & Österholm, Pär & $\begin{array}{l}\text { Unemployment and Labour-Force } \\
\text { Participation in Sweden }\end{array}$ & 2009 \\
\hline 114 & $\begin{array}{l}\text { Jonsson, Thomas and } \\
\text { Pär Österholm }\end{array}$ & $\begin{array}{l}\text { The Properties of Survey-Based } \\
\text { Inflation Expectations in Sweden }\end{array}$ & 2009 \\
\hline 115 & $\begin{array}{l}\text { Hjelm, Göran and } \\
\text { Kristian Jönsson }\end{array}$ & $\begin{array}{l}\text { In Search of a Method for Measuring the Output Gap } \\
\text { of the Swedish Economy }\end{array}$ & 2010 \\
\hline 116 & Vartiainen, Juhana & Interpreting Wage Bargaining Norms & 2010 \\
\hline
\end{tabular}




\begin{tabular}{|c|c|c|c|}
\hline 117 & $\begin{array}{l}\text { Mossfeldt, Marcus and } \\
\text { Pär Österholm }\end{array}$ & $\begin{array}{l}\text { The Persistent Labour-Market Effects of the Financial } \\
\text { Crisis }\end{array}$ & 2010 \\
\hline 118 & $\begin{array}{l}\text { Östblom, Göran, Ma- } \\
\text { ria Ljunggren Söder- } \\
\text { man and Magnus Sjö- } \\
\text { ström }\end{array}$ & $\begin{array}{l}\text { Analysing future solid waste generation - Soft linking } \\
\text { a model of waste management with a CGE-model for } \\
\text { Sweden }\end{array}$ & 2010 \\
\hline 119 & $\begin{array}{l}\text { Broberg, Thomas, } \\
\text { Per-Olov Marklund, } \\
\text { Eva Samakovlisa and } \\
\text { Henrik Hammar }\end{array}$ & $\begin{array}{l}\text { Does environmental leadership pay off for Swed-ish } \\
\text { industry? - Analyzing the effects of environ-mental } \\
\text { investments on efficiency }\end{array}$ & 2010 \\
\hline 120 & $\begin{array}{l}\text { Gustavsson, Magnus } \\
\text { and Pär Österholm }\end{array}$ & $\begin{array}{l}\text { Labor-Force Participation Rates and the } \\
\text { Informational Value of Unemployment Rates: Evi- } \\
\text { dence from Disaggregated US Data }\end{array}$ & 2010 \\
\hline 121 & $\begin{array}{l}\text { Jonsson, Thomas and } \\
\text { Pär österholm }\end{array}$ & $\begin{array}{l}\text { The Forecasting Properties of Survey-Based Wage- } \\
\text { Growth Expectations }\end{array}$ & 2010 \\
\hline 122 & $\begin{array}{l}\text { Antipin, Jan-Erik, } \\
\text { Jimmy Boumediene } \\
\text { and Pär Österholm }\end{array}$ & $\begin{array}{l}\text { On the Usefulness of Constant Gain Least Squares } \\
\text { when Forecasting the Unemployment Rate }\end{array}$ & 2011 \\
\hline 123 & $\begin{array}{l}\text { Broberg, Thomas, } \\
\text { Tomas Forsfält and } \\
\text { Göran Östblom }\end{array}$ & $\begin{array}{l}\text { The Excess Cost of Supplementary Constraints in } \\
\text { Climate Policy: The Case of Sweden's Energy Intensi- } \\
\text { ty Target }\end{array}$ & 2011 \\
\hline 124 & $\begin{array}{l}\text { Baard, Patrik, Henrik } \\
\text { Carlsen, Karin Ed- } \\
\text { vardsson Björnberg } \\
\text { and Maria Vredin } \\
\text { Johansson }\end{array}$ & $\begin{array}{l}\text { Scenarios and Sustainability. A Swedish Case Study of } \\
\text { Adaptation Tools for Local Decision-Makers }\end{array}$ & 2011 \\
\hline 125 & $\begin{array}{l}\text { Hansson, Sven Ove, } \\
\text { Karin Edvardsson } \\
\text { Björnberg and } \\
\text { Maria Vredin Johans- } \\
\text { son }\end{array}$ & $\begin{array}{l}\text { Making Climate Policy Efficient } \\
\text { Implementing a Model for Environmental Policy } \\
\text { Efficiency }\end{array}$ & 2011 \\
\hline 126 & $\begin{array}{l}\text { Antipin, Jan-Erik, } \\
\text { Farid Jimmy Boume- } \\
\text { diene and Pär Öster- } \\
\text { holm }\end{array}$ & $\begin{array}{l}\text { Forecasting Inflation Using Constant Gain Least } \\
\text { Squares }\end{array}$ & 2012 \\
\hline 127 & $\begin{array}{l}\text { Meredith Beechey, Pär } \\
\text { Österholm }\end{array}$ & $\begin{array}{l}\text { Policy Interest-Rate Expectations in Sweden: A Fore- } \\
\text { cast Evaluation }\end{array}$ & 2012 \\
\hline
\end{tabular}

